\title{
The Structure of Isoetes Hystrix.
}

\author{
BY \\ D. H. SCOTT, M.A., Ph.D., F.R.S., \\ Honorary Keeper of the Jodrell Laboratory, Royal Gardens, Kew,
}

AND

T. G. HILL,

Late Marshall Scholar, Royal College of Science, London.

With Plates XXIII and XXIV, and two Figures in the Text.

\section{INTRODUCTION.}

$\mathrm{T}$ April and May, I899, one of us received, through the 1 kindness of Mr. E. D. Marquand, a number of fresh specimens of Isoetes Hystrix, collected by Mr. George Derrick, a botanist resident in Guernsey, at the well-known locality on l'Ancresse Common, in that island, the only known British habitat for the species ${ }^{1}$. To both the gentlemen mentioned our best thanks are due. This material, which included plants of very different ages, afforded a welcome opportunity for a re-investigation of the structure in this form, which is of considerable interest as being one of the terrestrial species,

${ }^{1}$ See Mr. Marquand's note on the genus Isoetes, in Trans. Guernsey Soc. of Nat. Science, I889, p. I 23.

[Annals of Botany, Vol. XIV. No. LV. September, I900.] 


\section{I 4 Scott and Hill.-Structure of Isoetes Hystrix.}

of which, according to Baker's arrangement, there are only two (I. Hystrix and I. Duriaei) among the forty-nine species described in his 'Fern-Allies.' Although so much work has already been done on Isoetes, such a re-investigation does not appear superfluous, in view of the widely different views which prevail as to the affinities of the genus, and of the ever-increasing interest which attaches to the surviving Pteridophyta, as we become better acquainted with their history in past ages.

Our own observations relate entirely to the structure and development of the vegetative organs, for it is these points which appear most to need further elucidation, while the reproductive and embryological phenomena have been thoroughly investigated by our predecessors.

A terrestrial species, such as 1 . Hystrix, is clearly the most favourable for anatomical investigation, as the tissues are more characteristically developed than in the reduced, aquatic forms. In a genus, such as Isoetes, however, with so great a preponderance of aquatic or sub-aquatic representatives, we must regard it as an open question whether these, or the exceptional terrestrial forms, are the more primitive. In any case there can be no doubt that the terrestrial species share, to a considerable extent, in the reduction which characterizes the genus as a whole. (See below, p. 443.)

As regards the plan of the paper, after a few general descriptive remarks, the structure of the stem will be considered, then that of the leaves, and finally that of the roots. In conclusion, the systematic position of the genus and its relation to other Pteridophyta, recent and fossil, will be briefly discussed.

With reference to method, it need only be said that we have relied for the most part, though not exclusively, on serial microtome-sections, prepared by the usual paraffin process, and double-stained with safranin and haematoxylin. The small size of the plant and the softness of most of its tissues render it peculiarly amenable to microtome-treatment, and the study of complete series of sections, extending 
through the whole length or thickness of the stem has proved of great advantage ${ }^{1}$.

The Guernsey specimens of Isoetes Hystrix are small, the extreme length of the leaves not exceeding two inches, while the full diameter of the bulbous stem reaches about half an inch. The upper part of the short stem is covered by the swollen, sporangiferous bases of the living leaves, while the lower portion is enclosed in an armour of the persistent, spinose bases, almost black in colour, of the leaves of previous years. As is well known, the cortex is not, as a rule, thrown off in the terrestrial species of Isoetes, or only very slowly, so that the whole stem, or all except the oldest part at the base, remains protected by the spines.

All the specimens we examined had three furrows, separating three well-marked lobes. This is almost constant in the species, though four-lobed specimens have been described. Admirable illustrations of the habit of Isoetes Hystrix will be found in the monograph by Motelay and Vendryés, Plates XV and XVI ${ }^{2}$. The appearance of the three-furrowed stem, as seen from below, after removing the roots and spiny leaf-bases, is shown in our Plate XXIV, Fig. 29. The Guernsey plant appears to belong to the variety subinermis, of Durieu, as shown by the shortness of the spines (see Fig. 28), though the stems have not usually undergone the early desquamation, stated by Motelay and Vendryés (p. 490) to characterize this variety.

As the plant grows, in nature, the whole of the bulbous portion, including the bases of all the living leaves, is completely buried in the soil, so that only the tuft of narrow, green leaf-blades is exposed to view. Thus no sign of the presence of fructification is visible externally, and we have the rare case of a plant with subterranean organs of repro-

1 I desire to place on record that the great majority of the preparations, and the whole of the drawings, were the work of my colleague, Mr. T. G. Hill. On the other hand, I assume all responsibility for the theoretical views expressed at the conclusion of the paper.-D. H. S.

${ }^{2}$ For works cited, see the list of literature at the end of the paper. 
duction. The conditions under which fertilization and dissemination take place appear to deserve investigation. Possibly earthworms may play some part in the matter.

\section{The Stem.}

The general structure of the stem of Isoetes has been known for many years. A very accurate account of its main features, as shown in I. lacustris, a two-furrowed species, was given by $v$. Mohl in 1840 , and his bold, diagrammatic figures are admirably adapted to give an idea of its peculiarities. From that time onwards our present knowledge of the stemstructure has been gradually built up by the successive labours of Hofmeister, Alexander Braun, Russow, Hegelmaier, Bruchmann, Farmer, and others. Our knowledge is still imperfect as regards the mode of growth at the apex, the differentiation of the tissues, and the nature of the secondary growth. On these points we hope that some new light is thrown by our observations, to which we will now pass on, dealing with the statements in the literature as we proceed.

The short, three-lobed stem of Isoetes Hy'strix has a deep depression at the apex, at the bottom of which the growingpoint is situated. The sloping sides of the funnel-shaped depression are covered by the leaves, becoming successively younger as they approach the growing-point at the bottom of the funnel. In these respects there is no essential difference from the stem of other species, and various figures in the literature will serve to illustrate the general arrangement ${ }^{1}$. The growth of the stem in length is extremely slow, while the cortex, owing to the extension of the primary tissues, and to cambial activity, has a vigorous circumferential increase. It is the extraordinarily stunted form of the Isoetes-stem which gives rise to most of its peculiarities.

The stem is traversed longitudinally by a single stele; in its upper part the stele is cylindrical, while lower down the

${ }^{1}$ See, for example, v. Mohl, 1845, Pl. V, Figs. 9 and 10 ; Hofmeister, $185^{2}$, Pl. X, Fig. I, Pl. XII, Fig. I, \&c.; Wilson Smith, I900, Pl. XIII, Figs. 3 and 4. 
stem it becomes very markedly triangular, as seen in transverse section (cf. Plate XXIII, Figs. I3 and I4), the angles growing more prominent towards the base of the stem. The proportionate length of the cylindrical and triquetrous portions of the stele, though showing individual variations, remains approximately constant in the young and old stems. The transition from the one form to the other is gradual, and the exact limit therefore arbitrary, but roughly speaking, the upper, cylindrical portion occupies from about one-third to two-fifths of the whole length, while the lower, more or less triangular region, extends through the remaining two-thirds or threefifths. A precisely corresponding change in the form of the stele takes place in the two-furrowed species, only here the basal region is, in transverse section, an elongated ellipse, instead of a triangle (v. Mohl, l. c., Figs. 7 and 8). The projecting arms correspond in position to the furrows, and are due to the abutment of successive root-bases. As new roots arise in acropetal succession, the triangular region (in the threefurrowed species) gradually encroaches on the cylindrical, keeping pace with the general growth in length, and thus maintainiıg an approximately constant relation between the two regions. Thus every part of the stele is cylindrical in its young condition, and only assumes the triquetrous form with advancing age, as it becomes the seat of root-formation.

The stele gives off numerous leaf-traces, which start almost horizontally, and then, bending upwards, pass out one into each leaf. The whole stele bears leaf-traces, but they areusually only to be recognized on the upper, cylindrical portion; for lower down, the old traces have become more or less completely obliterated, and their continuity has been interrupted by the excessive growth of the secondary tissues through which they pass (cf. Hofmeister, I $85^{2}$, p. I49).

Before going on to consider the differentiation of the tissues, it is desirable to say something as to the apical growth of the stem as a whole, a point on which there has been much difference of opinion, and which is not yet cleared up. Hofmeister, as is well known, attributed the apical growth to 
a single apical cell, and even described its mode of division in considerable detail. At that time, however, th single apical cell was the only type of growing-point which had been investigated, and it was natural that the great morphologist should have endeavoured to refer the stem, at least of any Vascular Cryptogam, to that scheme. Later investigators have generally rejected his explanation. Hegelmaier ( 1874, p. 497) came to the conclusion that the meristem of the growing-point in I. velata and Duriaei, at which he worked, had the significance of an apical cell-surface: he appears to regard this initial layer as extending over the whole area of the apex. Bruchmann (1874, p. 570) found in the case of I. lacustris, a definite initial group, occupying the middle of the apex. The apex of the stem, however, as shown in his figures (Plate XXIV, Figs. 29-31), bears a suspicious resemblance to a young leaf. Farmer, on the other hand (I890, Plate V, Figs. I3 and I4), working with serial sections, no doubt observed the true apex of the stem, which is comparatively flat. He finds that 'the entire apex of the stem is covered by a columnar layer of cells, which divide chiefly anticlinally, periclinal divisions only occurring at long intervals' (p. 39). He thus practically returns to Hegelmaier's conclusion, and makes no attempt to identify a definite apical group. Van Tieghem (I89I, p. I429) states that the stem grows 'like that of the Lycopods, by a single small mother-cell.' We are not aware on what grounds this statement is made. Our own observations, while by no means decisive as to the mode of growth, show that Hofmeister's opinion is at least defensible. In good transverse sections through the actual apex, we several times detected a large cell, or two large cells, in a central position. Fig. I is from a section showing the surface of the growing-point. A pair of large cells, with larger nuclei than their neighbours, is conspicuous at the centre of the apical region. The wall between them is delicate, which favours the idea that the larger of the two may be the actual apical cell, while its slightly smaller companion may be a segment just cut off from it. This was from one of the larger stems. 
Fig. 2, from another, younger specimen, shows a transverse section passing immediately below the actual surface of the apex ${ }^{1}$. The large, somewhat triangular cell, with a large nucleus, is strongly suggestive of an apical cell, from which segments have been cut off.

A third transverse series showed a similar predominant cell at the centre of the apex, towards which the surrounding meristem appeared to converge in radial series.

Other specimens, cut transversely, gave no decisive results.

Longitudinal series require the greatest care, in order to determine which is the median section. The apex is so flat that its form gives little or no guidance, and we were only able to satisfy ourselves as to the median plane, by counting the serial sections, and choosing the middle one, i. e. that which is equidistant from the youngest leaves on either side. We much doubt whether, in this species, the point could be determined without the aid of serial sections.

Fig. 3 represents a longitudinal section through the centre of the growing-point. It shows a central cell $(a)$ deeper than the rest, and with a large nucleus. On the left a segment appears to have been cut off, and then subdivided by a transverse wall. Fig. 4, from one of the adjacent sections, misses the large cell, but shows at $s$ what appears to be a subdivided segment.

It is no doubt possible that the various appearances described, pointing to the presence of a single apical cell, may be accidental, the large cell having no special relation to the general growth. With such a slow-growing apex, it is difficult, or perhaps even impossible, to arrive at certainty. It is, however, a somewhat unexpected fact, that whenever any definite arrangement could be detected, it appeared to favour the hypothesis of an apical cell. Our observations may at least serve to explain, if they cannot establish, the opinion of Hofmeister.

The central cylinder of the stem is derived from a plerome-

1 These are thin microtome-sections, about $6 \mu$ in thickness, so that the section drawn shows the same cells as at the surface. 


\section{Scott and Hill.-Structure of Isoetes Hystrix.}

like column of tissue, the cell-rows of which converge upwards, towards the central part of the apex. As we follow the cylinder downwards from the apex, in successive transverse sections, we find that it very rapidly assumes mature structure. The leaf-traces, where they abut on the stele, are somewhat more differentiated than the stele itself, and have their xylem lignified at a level where the central tissue is still in a meristematic condition. Immediately below this point, however, and at a distance not exceeding $\cdot 15 \mathrm{~mm}$. from the apical surface, the differentiation of the stelar wood suddenly begins. The lignification at first extends irregularly across the stele, connecting the leaf-traces together, but in the next section of the series it may be already complete (Fig. 5). Where the differentiation is so nearly simultaneous it is perhaps futile to seek to determine its direction. In some cases, however, a centripetal development can be traced, as shown in Fig. 6, where the outer stelar tracheides are fully formed, while the central tissue is still undifferentiated. At a slightly lower level, the central tracheides are sometimes found partially lignified, while those towards the periphery are completely formed.

The primary tracheides are extremely short, corresponding to the stunted character of the stem, and their chief diameter is usually horizontal. The thickenings on their walls are mostly spiral, but annular and reticulate markings also occur here and there.

Among the tracheides a considerable amount of thin-walled parenchyma is interspersed, the cells of which retain their nuclei, and remain living when the lignified elements between them are already disorganized.

Fig. 5, from the youngest stem at our disposal, which was little more than $2 \mathrm{~mm}$. in diameter, gives as far as possible a representation of the primary structure of the stele, as seen in transverse section. It is however impossible to find the structure in a purely primary condition, for the cambial divisions begin before the primary differentiation is completed. In all the stems examined, whether old or young, tangential 
divisions around the periphery of the stele were well marked, at a level above the commencement of lignification of the primary tracheides. These divisions take place in cells immediately outside those which differentiate into the wood of the stele. No demarcation between pericycle and cortex could be detected.

The question of the existence of phloem in the stem of Isoetes has been left in a very unsatisfactory condition, so much so that the latest writer on the genus, Wilson R. Smith (I900, p. 227), proposes to drop the application of the word phloem altogether 'until its justification shall be established on physiological grounds.' This seems rather a remote contingency in the case of a genus like Isoetes, and it is well that the anatomy does not leave us so entirely in the dark. Mr. Wilson Smith treats the whole of the so-called prismatic zone, i. e. the secondary tissue lying on the inner side of the cambium, and thus immediately surrounding the primary cylinder, as one tissue, and argues against its being regarded as phloem, on the ground that some of its elements may become converted into tracheides. As a matter of fact the 'prismatic zone' within the cambium is sharply differentiated into three kinds of tissue-secondary parenchyma, secondary wood, and the true phloem. As was first detected by Hegelmaier (1874, p. 500), this zone consists of alternating, concentric bands of starchcontaining tissue, and of cells without obvious contents. The existence of this differentiation can always be detected, though more obvious in the older stems. The starch-containing cells retain their nuclei, while the phloem-cells soon lose theirs; in young phloem-cells, granules which probably represent the disorganizing nuclei are often present. The presence of an enucleate zone is easily recognized, even apart from other characters, in stained sections. It is usually first differentiated immediately within the cambium, and separated from the primary wood by a layer or two of parenchyma (see Fig. 5). The phloem-elements have an extremely characteristic structure of their cell-walls, which comes out conspicuously in sections deeply stained with haematoxylin. Their walls are 


\section{Scott and Hill.-Structure of Isoetes Hystrix.}

much pitted, the thicker bands of membrane, between the pits, forming a lattice-like reticulum (see Figs. 7 and 12). The pits are often subdivided by fine bars, into smaller areas. Little of the nature of formed contents can usually be detected, but sometimes small, deeply staining globules are found adhering to the walls, and apparently localized at the pits (Plate XXIV, Fig, I6). In the older parts of the stem the phloem is to a great extent obliterated, dense masses of callus-like substance appearing on the cell-walls, and almost fitting the cavity (Fig. 17). These masses stain like callus with coralline-soda, but the other callus-reactions tried did not give wholly satisfactory results, and, unlike true callus, these masses are apt to shrink away from the cellwalls. In their deep staining with haematoxylin they agree with the true callus in the sieve-tubes of the foliar bundle.

We have not investigated the more minute histology of the phloem, and thus have not demonstrated the perforation of the thin-walled areas. That may be left to other investigators, but in the meantime, we can scarcely doubt that these enucleate elements, with the characteristic areolation of their walls, and their agreement in various reactions with the sieve-tubes of the leaf, with which, as we shall see, they are continuous, are best to be regarded as themselves representing the sieve-tubes of the stem. In any case we must apply the name phloem to them exclusively, in describing the stem-anatomy.

Russow detected these elements as long ago as 1872 (p. I 39) and described them quite clearly. He says :- 'The tabular or shortly prismatic cells have clearly thickened and finely pitted walls, and in transverse section make quite the impression of sieve-tubes or latticed cells in Coniferae: in their function they certainly agree with the bast-elements mentioned : their difference in form from sieve-tubes is explicable by the conditions of growth of the organs in which they occur.' Considering that Russow worked with herbarium-material, the accuracy of his description is wonderful, and it compares extremely favourably with later statements. He does not, 
however, distinguish between the latticed cells and the ordinary intracambial parenchyma. This distinction, as already mentioned, was first drawn by Hegelmaier, but he failed to make out the latticed structure of the 'empty' cells, owing no doubt, as he himself suspected, to defective optical appliances (1.c., p. 503). Farmer (I 890 , p. 42) confirms Hegelmaier's account of the alternating zones.

Russow regarded the secondary intracambial tissue as phloem, which is no doubt correct, but with the limitation that only the latticed elements, forming part of that zone, are the true phloem. The parenchyma alternating with the phloem-bands is best regarded as secondary ground-tissue, not as phloem-parenchyma, for there is no reason to associate it with the phloem any more than with the secondary xylem, which forms part of the same region.

Speaking generally, the whole of the phloem in the stem of Isoetes must be regarded as secondary, for it belongs to the tissues cut off on the inner side of the cambium. It is not usually possible to identify any primary phloem with certainty. In fact the tangential divisions begin so early that it would scarcely be practicable to distinguish between primary and secondary structures, at the periphery of the stele. In certain cases, however, the cambium at its first origin is a normal one, the phloem-elements lying on its outer side, and in these instances the extra-cambial phloem may be reasonably regarded as primary. (See Fig. 8.) It may here be pointed out that the tissue in immediate contact with the primary wood, which Hegelmaier inclined to regard as phloem (I874, p. 502), is certainly not of that nature, as it is always parenchymatous, with none of the characters of the phloem.

Not infrequently the cambium, at its first origin, cuts off a few secondary xylem-elements in contact with the primary wood (Fig. $7, x^{2}$ ). In one stem the only secondary wood found was in this position. These indications of a normal cambial development are of some interest, as suggesting the possibility that the anomalous secondary growth of Isoetes may have been derived from a more regular mode of thickening, 


\section{Scott and Hill.-Structure of Isoetes Hystrix.}

such as obtained in Sigillaria and most Lepidodendreae of which the structure is known. On the whole, however, the process in Isoetes more nearly resembles that occurring in Lepidophloios fuliginosus, the most irregular of the Lepidodendreae in its secondary growth.

The cambium, in I. Hystrix, arising in the tissue just outside the xylem-cylinder, continues its activity indefinitely, producing parenchyma and phloem, and a variable amount of secondary xylem, on its inner side, and secondary cortical parenchyma only, towards the exterior. Where the cambium is at first a normal one, with phloem on its outer side, its activity is of short duration, and it is immediately replaced by a new generative layer, arising further to the exterior. Usually the cambium, from its first origin onwards, is anomalous, in so far as it produces phloem towards the interior exclusively. There is no regular formation of successive cambial layers : the same layer may apparently continue active throughout the secondary growth. In two cases, however, a new cambium, internal to the first, was observed, arising by the division of secondary parenchymatous cells just outside the primary wood. As this internal cambium did not exist nearer the apex, the presumption is that it was really of later origin than the more external zone. The activity of the two cambial layers had produced some crushing of the elements between them. The inner cambium, like the outer, may produce all three tissues-phloem, wood, and parenchymaon its inner face.

The active cambial layer can be readily identified by its narrow, tabular cells, containing dense protoplasm, and each with a large nucleus. In this species, at any rate, the cambial cells do not contain starch, as Wilson Smith maintains to be the case in the species investigated by him (p. 227).

The alternating, though not very regular zones, of parenchyma and phloem, are a constant feature of the intracambial tissue. In an old stem we counted from eight to ten layers of each.

On the other hand the development of the secondary wood 
is extremely variable, though it is always present to a greater or less extent. In one stem of fair size we found, as already mentioned, no other secondary tracheides than the few occurring immediately outside the primary wood. In other stems, one or more irregular bands of secondary wood are differentiated here and there between the phloem-zones (Fig. IO). Sometimes the secondary tracheides are isolated (e.g.Fig.9); in other cases they form considerable aggregations, as shown in Fig. II, from a specimen in which there was an almost continuous band of secondary wood round the stem. There is no doubt that the elements of the secondary, like that of the primary wood, are true tracheides, which not only acquire ligniffed thickenings on their cell-walls, but lose their living contents. The statement made in the case of $I$. lacustris, that these elements contain protoplasm and starch, certainly does not hold good for I. Hystrix (Farmer, I 890, p. 42 ; Campbell, I 895, p. 29I). The secondary tracheides, where they occur, are perfectly sharply differentiated, and agree in all important respects with those of the primary wood.

The extracambial secondary cortex does not attain such a great development in $I$. Hystrix, where the primary cortex is not exfoliated, as appears to be the case in some other species. The thickness may even be less than that of the intracambial secondary tissue, especially low down the stem. There are some indications that the secondary cortical cells may undergo further divisions after they are cut off by the cambium.

Thus the secondary growth of the Isoetes stem is on the whole anomalous, if we take the typical Gymnospermous or Dicotyledonous stem, or that of most of the Lepidodendreae, as the standard of comparison. Its peculiarity consists in the fact that as a rule, though not invariably, the true phloem, as well as the secondary xylem, is formed on the inner side of the cambium, accompanied by secondary ground-tissue, while on the outer side, ground-tissue alone is produced. The mode of growth is thus roughly comparable to that of the Monocotyledons, such as Dracaena, Tamus, or Aristea, with secondary tissue- 
formation. The Monocotyledonous analogy was first clearly pointed out by Russow (1872, p. I58), though it had already been suggested, on less definite grounds, by v. Mohl (1845, p. 125) and Hofmeister (1852, p. I59). Later authors have usually referred to this analogy, which is of course of no value as an indication of affinity.

Most investigators have regarded the stele of Isoetes as built up of leaf-traces, and as having no cauline portion. This is the view of Hofmeister, Russow, Sachs, De Bary, and among recent writers, of Farmer and Campbell. Farmer, however (1890, p. 40), allows that the distinction lies 'rather in the mind of the investigator than in the actual object before him.' It seems to us to be somewhat arbitrary to speak of a vascular cylinder as built up of leaf-traces when it is manifestly impossible to refer its constituent elements to the particular leaf-trace to which they belong. Isoetes appears to have a cauline stele just as any monostelic Lycopod has, only in the former the stele is much shorter than in most Lycopods, and the leaf-traces joining it more crowded. The stelar wood serves to join up the xylem of the leaf-traces, but does not belong to one trace more than to another, and in structure it differs obviously from that of the leaf-traces. We therefore prefer to adopt the view of Hegelmaier and Bruchmann ${ }^{1}$ that the xylem-cylinder is cauline. The phloem is certainly cauline but hardly comes into the question, as the primary phloem can so rarely be identified. The view of the central cylinder as cauline of course applies to the adult stem only; in embryonic stages, according to all investigators, the construction of the vascular system from the union of definite leaf-traces is indisputable. Similar differences between the embryonic and adult stem obtain in certain species of Lycopodium.

Russow maintained that his 'phloem,' i. e. the intracambial zone generally, was continuous with the phloem of the leaftraces. Some other authors have disputed this, e. g. Mr. Wilson Smith in his recent paper (1900, p. 227). Our own observa-

\footnotetext{
${ }^{1}$ Hegelmaier, 1874 , p. 505 ; Bruchmann, 1874 , p. 570 .
} 
tions completely confirm Russow's statement, but give it greater precision. The phloem of the leaf-traces (as to the nature of which there is no longer any doubt) passes over directly into those latticed elements of the intracambial zone, which alone constitute the true phloem of the stem (Fig. I2). At the point of junction, transitional elements occur, which belong equally to the leaf-trace and to the cauline phloem.

As we follow the stele downwards, we find that its primary wood becomes more and more disorganized, the tracheides breaking down so completely that they must become perfectly functionless. The parenchymatous elements of the wood remain living, and appear even to grow in length, forming a trabecular network, in the meshes of which the remains of the disorganized tracheides are scattered. Possibly a pull may be exerted on the central wood by the leaf-traces, when stretched in consequence of secondary growth (Farmer, I 890, p. 4I), but if so it has little effect in enlarging or distorting the cylinder, which is smaller in the lower than in the upper part of the stem, and usually shows little change from its normal cylindrical form.

The change to the triangular section of the basal part of the stele, as above explained, is due to the development of the adventitious roots. In I. Hystrix, the roots are developed along three lines, corresponding to the three furrows. The root-bearing furrows start from the centre of the base of the stem, and run outwards and upwards, dying out below the region of the living leaf-bases (see Plate XXIV, Fig. 29). The three prominent arms, seen in transverse sections of the lower part of the stele, correspond in position to the three furrows.

The structure of the basal part of the stele in Isoetes depends so completely on the distribution and development of the roots that a few words on this subject are necessary here, though the structure of the roots themselves will be deferred till later.

The order of succession of the roots of Isoetes appears to have been first correctly made out by Hofmeister. We worked 
out the order for ourselves in I. Hystrix, and as the published accounts are not altogether clear, we have thought it worth while to illustrate the subject by the two accompanying diagrams (Figs. II and $I 2$ in the text), which were made from camera-lucida drawings, so that the position of the roots is exact. The relative age of the roots could be determined by their state of development, the oldest root-traces having their vascular tissues more or less obliterated, while the youngest were still wholly meristematic, and all intermediate stages

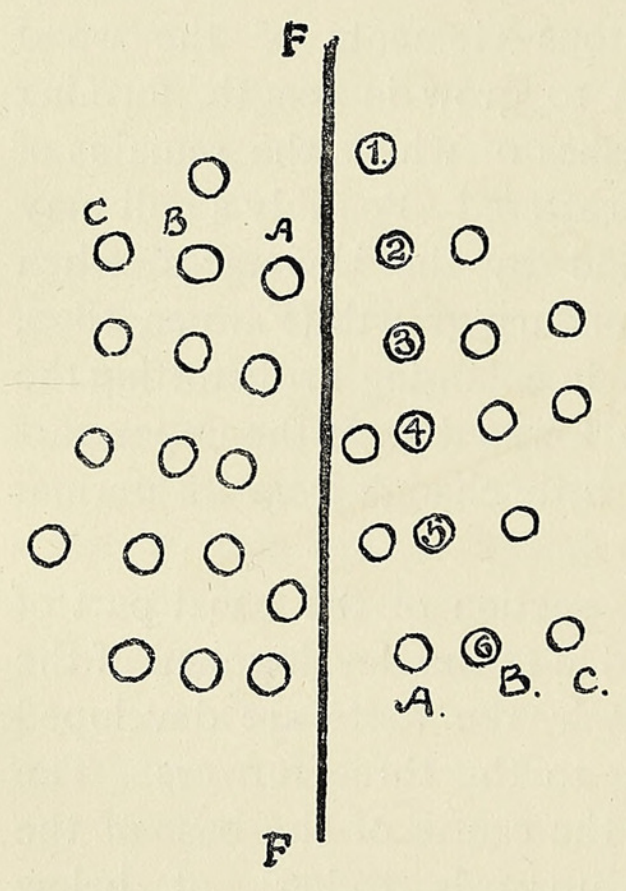

Fig. I I. Diagram of the root-succession in I. Hystrix, as shown in a tangential section of the stem, at right angles to a furrow. were represented. Both sections pass through the region of the root-bases. Fig. 12 is from a transverse section through the base of the stem, while Fig. II represents a tangential section, from the side of the stem, cut at right angles to one of the furrows.

The succession of the roots of Isoetes, like that of most other adventitious roots, is an acropetal one. Yet new roots are constantly arising on the base of the stem. The apparent contradiction is thus explained: the roots, in our species, are arranged in three sets, corresponding to the three furrows. We will fix our attention on one set. The roots are arranged in several parallel series, on each side of the median line of the furrow ( $F$ in the diagrams); the whole set of roots extends from near the centre of the basal surface of the stem outwards, and for a certain distance up the flank. In each series the succession of the roots is acropetal, the oldest being nearest the centre of the base of the stem, and the youngest highest up on the flank. But, at the same time, new series are being 
Scott and Hill.-Structure of Isoetes Hystrix. 429

started, each lying nearer the median line of the furrow than its predecessor. Hence we may at any time find new roots arising near the centre of the basal surface ; these belong to new rows which have only just started. With reference to the whole stem, the succession of the roots in each series is thus acropetal, while the succession of the series themselves is centripetal, with reference to the centre-line of the furrow to which they belong. In Figs. II and 12 the succession

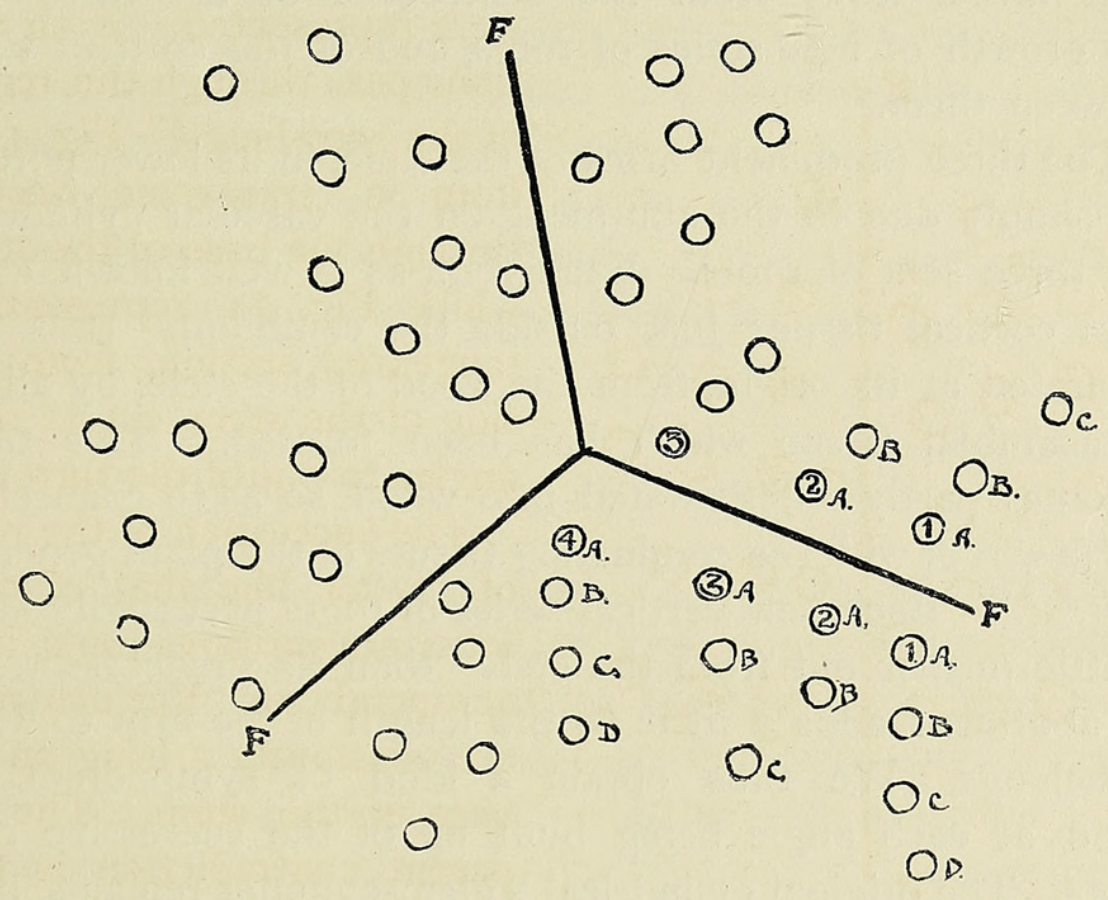

Fig. I2. Diagram of the root-succession, as shown in a transverse section from the base of the stem. For description see text.

within each series is represented by numbers, No. I being the youngest root shown in its series; the succession of the series themselves is represented by letters, $A$ being the youngest series of its set. There will usually be two, about equally young series, one on each side of the median line of the furrow. It would rarely happen that the same series could be traced through its whole course. The older series would usually be obliterated near the base of the stem, while the younger series would be incomplete towards the apex. It 


\section{Scott and Hill.-Structure of Isoetes Hystrix.}

will be noticed that in Fig. I I (which being from the side of the stem, shows only the younger roots of those series which reach so far) an intermediate row on each side is the longest. This is so, because the younger series, towards the middle, are not yet carried so far up, while the older series, towards the outside, were completed while the whole root-bearing region was shorter.

The older and outer series of each set get pushed further and further away from the centre-line of the furrow by the growth of new series of roots, and of the cortical tissue between them.

The three prominent arms of the stele, in its lower portion, are simply due to the abutment on the vascular cylinder of the three sets of roots. Each root, as is well known, arises from cortical tissue ${ }^{1}$ just outside the cambium. It is thus separated at its origin, from the wood of the stele, by all the intracambial tissue which has been formed. This tissue becomes partly differentiated into wood, so as to connect up the new root with the conducting tissues of the plant generally (Fig. I5). Each new vertical series of roots necessarily arises a little further out from the stele ${ }^{2}$ than its predecessor, and its abutment adds a little to the length of the arm to which it belongs. We thus obtain a kind of sympodium, the wood at each angle being built up of the successive rootbases. The original cylindrical xylem-cylinder remains, more or less unaltered, in the middle of the whole structure. The same thing is going on at the base of the stem, as new series of roots start there. Their bases join on successively to the bottom of the stele.

It has long been known that the base of the stem of Isoetes has a slow downward growth, a fact which much exercised the earlier writers. Von Mohl (1845, p. I25) discusses, and leaves undetermined, the question whether Isoetes

\footnotetext{
1 We use the word cortical because the attempt to delimit a pericycle appears quite hopeless in the case of the Isoetes-stem.

2 This will be evident on comparing Text-fig. II with Plate XXIII, Figs. I4 and $\mathrm{I}_{5}$.
} 
possesses a 'caudex descendens,' comparable to the tap-root of a Dicotyledon ; Hofmeister (1852, p. I 59) lays great stress on the Dicotyledonous analogy. As a matter of fact, the downward growth is due to the cambium, which at the base of the stem appears to form secondary parenchyma only; the wood which is added at the bottom of the stele, and which remains functional when the primary wood higher up is disorganized, is entirely built up by the sympodium of root-bases. There is thus no real similarity to the apical growth of a tap-root, though there is a physiological analogy, in so far as the Isoetes arrangement allows of the constant development of new roots at the base of the axis. The furrows owe their origin to the cambial growth being checked along the lines where the root-bases are attached, while it attains its maximum between them.

\section{THE LEAVES AND LEAF-TRACES.}

The structure and development of the leaves of Isoetes, and of $I$. Hystrix in particular, have been admirably elucidated by Kruch (I 890 ), whose accurate investigations have been confirmed in almost every point by our own observations ${ }^{1}$. A short statement of our results will therefore suffice.

The mature leaf of Isoetes Hystrix, as seen in a transverse section of the lamina, i. e. above the sheathing base, has the structure represented diagrammatically in Plate XXIV, Fig. I 8. The sectional form is roughly triangular, with the broad base of the triangle forming the upper or ventral surface. The mesophyll is traversed by four large intercellular spaces, alternating with which are four strands of mechanical fibres (Fig. 23), two at the ventrolateral corners, one at the middle of the ventral surface, and one at the dorsal angle. In this species the intercellular spaces are roofed in by the epidermis only; the stomata are limited to those bands of the epidermis

1 For a translation of a great part of the Italian text of Dr. Kruch's paper, we are inciebted to the kindness of Mr. L. A. Boodle, F.L.S. 
which cover in the cavities. Each of these bands bears three or four alternating longitudinal rows of stomata.

Longitudinal sections show that the intercellular cavities are partitioned at intervals by transverse diaphragms, one cell thick in the middle, but thicker where they abut on the surrounding mesophyll, which constitutes the assimilatory tissue. The middle of the leaf is traversed by the vascular bundle, surrounded by a small-celled parenchyma. The structure of the vascular bundle is obviously collateral (Fig. I9).

About the middle of the bundle is a well-marked, circular, intercellular space (Fig. 19, $p x$ ), and on either side of this there is often a smaller space of similar form. On the inner, ventral side of the intercellular spaces are the tracheides, not more than about eight or nine in number, forming an irregular transverse band, and usually separated from one another by xylem-parenchyma. The thickenings of these tracheides are, as a rule, annular (Fig. 22). On the outer side is the phloem, somewhat crescentic in sectional form (Fig. I9, ph), with the horns of the crescent occupied by the smaller elements. In the mature bundle it appears to be the case, as stated by Kruch, that the sieve-tubes are limited to the lateral horns of the crescent, for none were found, at maturity, in the median position. The elements of the phloem, where fully developed, have thick, cellulose walls, so as to have the appearance of mechanical elements, though only sieve-tubes and phloem-parenchyma are represented.

Both the central and lateral cavities of the bundle are surrounded by an endodermis, with suberized radial walls, showing the characteristic dark dots. This curious fact was first discovered by Russow (I872, p. I40), and is well illustrated by Janczewski (I882, P1. IV, Fig. 8). Kruch (1890, p. 6I) did not find the endodermal structure in his specimens; it is most distinctly present in ours, and the radial walls resist the action of sulphuric acid. Strasburger has already pointed out (I89I, p. 464) that the endodermal differentiation varies with the conditions. Our observations show that it may be characteristically present in a purely terrestrial 
species $^{1}$. As Kruch pointed out, the wall lining the cavity is distinctly suberized. As Janczewski first showed (1882) and Kruch demonstrated in detail (1890, pp. 61, 70), the canals in the foliar bundle of Isoetes represent disorganized xylem-elements; the large central canal takes the place of the actual protoxylem, the first-formed row of tracheides (Fig. 20, $p x$ ). These are of rather large size, with transverse walls, which persist for a long time, and are pulled widely apart by the growth in length of the leaf, so that in a microtome-series from a partly-developed leaf, one wall was seen about every hundred sections. These transverse walls or diaphragms are lignified and reticulated, and are perforated, at least when old (Fig. 2I; cf. Fig. 22, $p x$ ). Strasburger has shown that these canals in the bundle of Isoetes contain water, so it appears that they continue to perform tracheal functions. The tracheides corresponding to the lateral canals develop rather later, and so become less disorganized. In the upper part of the leaf they usually persist as tracheides, so that here there is only the one median canal, and it is then only around the latter that the endodermis is differentiated. The first-formed tracheide, as we have seen, is the outermost, so that here the wood is developed centripetally (with reference to the centre of the stem), as Russow states.

The protophloem, which is differentiated earlier than the protoxylem, forms a short band of apparently empty elements, with deeply-staining cellulose walls (sieve-tubes according to Kruch), lying immediately opposite the first tracheide (Fig. 20, $p p h)$. This median phloem becomes obliterated, and it is only the later-developed sieve-tubes of the lateral phloembands which remain functional. Kruch (1890, p. 70) and Strasburger (1891, p. 463) state that new sieve-tubes are added to the lateral bands, towards the dorsal (outer) side, and this appears to be the case.

The sieve-tubes, though small and difficult to investigate,

1 The endodermal markings are not shown in our figures, as the microtome preparations were not favourable for demonstrating them. They were quite clear in sections mounted in glycerine. 


\section{Scott and Hill.-Structure of Isoetes Hystrix.}

appear to have the typical structure. Fig. 24 shows, in vertical section, a transverse sieve-plate, which is thickened by a callus-deposit. Sieve-areas also occur on the lateral walls, and on these also, swollen masses, giving the reactions of callus, are formed (Fig. 25).

Towards the sheathing base of the leaf the structure changes considerably. The mechanical strands die out, the stomata diminish in number and ultimately cease, and the mesophyll here contains little or no chlorophyll. At the level of the glossopodium the four cavities of the mesophyll come to an end. Lower down, two new cavities appear, one on each side, and at the level of the sporangium these cavities take up a position in the wings of the leaf, on either side of the velum. As regards the vascular bundle, the number of xylem-elements increases in the centripetal direction; the three intercellular spaces of the xylem are extremely conspicuous in the region immediately above the base of the ligule. Still lower down, opposite the sporangium, the structure of the bundle undergoes a more important change. No intercellular spaces are formed in the xylem, which here consists of a considerable number of small tracheides, intermixed with parenchyma. Kruch ( 1890 , p. 76) states that the xylem in this region, and in the leaf-traces, is not always entirely centripetal, but that some elements are added towards the phloem. This statement is confirmed by our own observations, which in some cases showed developing tracheides between the first-formed xylem-elements and the phloem. Thus the foliar bundle towards its base tends to pass from exarch to mesarch structure.

The median protophloem is persistent in this part of the leaf, so that the layer of sieve-tubes forms a continuous arc when mature, and is not divided into two lateral groups as in the lamina, higher up.

The base of the deep-seated ligule is surrounded by a very conspicuous sheath of tracheides, as described by many previous writers (see Fig. 27). These tracheides, which are developed early, are especially abundant on the ventral side 
of the ligule, at the base of the labium. When the leaf is mature, this sub-ligular xylem, which is not so strongly lignified as that of the foliar bundle, may nearly reach the latter, but we have never observed actual continuity between the two tissues.

The leaf-traces, where they pass through the cortex of the stem, are collateral in structure. Near the stele, the xylem, which is well developed, is made up of elements in close contact with one another, while in the outer cortex the tracheides are separated by parenchymatous cells. The phloem is well marked; the elements composing it, which are separated from the xylem by parenchyma, present all the characteristics of the protophloem of the leaf, in shape, size, thickness of walls, and the decided blue colour which they take up when stained with haematoxylin.

The leaf-traces, where they traverse the outer cortex of the stem, are practically identical in structure with the bundle of the leaf in the region of the sporangium.

Immediately before joining the central wood, the leaf-trace of course shows no phloem; here it is surrounded by a welldefined zone of parenchyma, the outer boundary of which marks the limit between the leaf-trace and the surrounding, growing tissue of the intracambial zone.

The development of the leaf is well known, and may be briefly dealt with. It arises as a dome-shaped mass of tissue, from the superficial layers of the apex, and grows at first towards the centre of the apical depression. The ligule is the first part of the leaf to be differentiated. It arises from a single cell, which grows enormously in size, while the leaf is still quite small. The first divisions in this cell are transverse. Longitudinal growth takes place very rapidly, so that the ligule becomes bent over the apex of the young leaf ${ }^{1}$. The transverse growth of the ligule is also considerable, so that it exceeds the young leaf in width.

The velum arises from a band of tissue, the sella (saddle)

${ }^{1}$ The development of the ligule and its mature structure are fully described in the papers of Farmer, Campbell, and Wilson Smith. 


\section{Scott and Hill.-Structure of Isoetes Hystrix.}

of A. Braun (1863, p. 569), lying between the young sporangium and the ligule. It is certainly not the case in I. Hystrix that it arises as 'a sterilized portion of the sporangium,' as Wilson Smith maintains (1900, p. 242). The first growth from the saddle is in the upward direction; to form the labium of A. Braun (Fig. 26). The upward growth soon ceases, and the velum develops in the downward direction, keeping pace with the growth of the sporangium, around which it forms a complete pocket, open only by a narrow crevice at the lower end (Fig. 26). This opening was called the micropyle by Braun. The complete velum is characteristic of the terrestrial species of Isoetes. As the velum is perfectly continuous with the leaf at the sides, as well as at the upper end, its development must take place by intercalary growth, proceeding pari passu with that of the leaf-base and sporangium.

Practically the whole growth of the leaf is intercalary, the growing region being at first localized at the level of the sporangium, and subsequently extending higher up, above the insertion of the ligule. It is only at the first origin of the leaf that there is any apical growth.

The development of the persistent, spinose leaf-bases of Isoetes Hystrix was fully worked out by Alex. Braun (1863, p. $57^{8}$ ), whose account we have simply to confirm. The facts are briefly these. A transverse ring of tissue at the base of the leaf, extending up to the lower edge of the sporangium, greatly thickens the walls of its cells, so as to form a continuous armoured belt. The sclerotic belt reaches the dorsal and ventral surfaces, and may include the lower part of the velum, but it does not extend out into the wings, the thin part of which withers away. At certain points the sclerosis extends further upwards, forming the spines. These may be four in number: there are two lateral horns, formed from tissue at the insertion of the wings, a ventral tooth formed partly from the velum and partly from tissue on the opposite side of the sporangium, the remains of which are thus partially enclosed by the sclerotic region, and lastly there may be a dorsal tooth, which 
is scarcely developed in our short-spined form. All these spinous structures are firmly seated on the sclerotic belt below. The inner tissue of the leaf-base remains living, and, when the lamina is thrown off, is covered in by a transverse plate of hard black tissue.

The whole structure is called by Braun the phyllopodium, a term which has since been used by Bower in a much more extended sense. In the reduced sterile leaves almost the whole organ is used up to form the persistent scale. The appearance of the ordinary spinose leaf-base is shown in Fig. 28.

\section{THe Roots.}

As regards the apex of the root we have nothing to add to the results of previous observers. In this case there can be no question that the earlier writers (Hofmeister, $185^{2}$, p. I $3^{6}$; Nägeli and Leitgeb, I868, p. I 35) were mistaken in referring the growth to a single apical cell, while Kienitz Gerloff (I88I, p. 793) was equally in error in regarding the tissue of the apex as 'a completely indifferent meristem.' Bruchmann, Farmer, and Campbell have proved conclusively that the root-apex possesses distinct histogenetic layers. The plerome is perfectly well defined. Bruchmann (1874, p. $\left.55^{6}\right)$ and Farmer $(1890$, p. 52 ) find that it grows by means of a single initial cell ${ }^{1}$. Some of our sections appear to confirm this result in the case of $I$. Hystrix, but we doubt whether it holds good constantly in our species. Beyond the plerome the most distinct demarcation is between inner and outer cortex (Farmer, 1890, p. 5I).

It appears that the later growth of the root is intercalary, so that the apex can only be studied with advantage in quite young roots.

Dichotomy of the roots takes place very early, while the apex is still buried in the tissues of the stem.

The anatomical structure of the mature root of Isoetes is

${ }^{1}$ Compare also Nägeli and Leitgeb, I868, p. I34, 'Der Cambiumcylinder ist anfangs immer einzellig.' 


\section{Scott and Hill.--Structure of Isoetes Hystrix.}

well known, and is illustrated, somewhat diagrammatically, in Fig. 30.

The position of the stele is from the first somewhat eccentric; a large intercellular space arises in the cortex, by breaking down of its internal layers, on one side of the stele, while, on the opposite side, continuity between central cylinder and cortex is maintained. As regards the external tissues, the chief point of interest is the presence of short cells-the 'trichome-initials' of Bruchmann (1874, p. 566)-in the superficial layer, a point in which the root of Isoetes agrees with that of Lycopodium. It is from these cells only that the root-hairs, which are very abundant in I. Hystrix, take their rise.

The structure of the stele is in all cases monarch. There is a single group of xylem, with a single band of phloem, forming a horseshoe on one side of the wood (Figs. 30, 3I). The orientation of the tissues is such that the xylem of all the roots, where they spring from the stem, is turned towards the centre-line of the furrow; the phloem, as well as the intercellular cavity, which always lies on the phloem-side, are directed towards the margins of the furrow.

The stele is surrounded by an endodermis of the usual structure, which is clearly of common origin with the inner cortex. The pericycle is incomplete on the side opposite the middle of the phloem.

The wood consists for the most part of densely spiral or annular tracheides, somewhat reticulated in places. The first tracheide to be differentiated lies on the side of the xylem remote from the phloem, as shown in Fig. $3^{2}$. From this point the development advances outwards, though not in perfectly regular succession, until the xylem is complete. The protoxylem in the roots of the adult plant is, as a rule, separated by the pericycle from the endodermis; in the first root it appears, according to Bruchmann (1874, p. 565) and Farmer (I 890, Pl. V, Fig. 4) to be in contact with the latter layer.

The protophloem is recognizable before the differentiation of the xylem begins, and forms an arc, in immediate contact 
with the endodermis, and at the opposite side from the protoxylem (Fig. 32). There is thus no distinction between the monarch strand of the Isoetes root, and an ordinary collateral bundle of the endarch type.

Where dichotomy of the root takes place, the plane of division passes through the protoxylem and protophloem. A stele at the base of a dichotomy is shown, in transverse section, in Fig. 34. As the two strands separate from each other they turn through an angle of $90^{\circ}$, so as to direct their protoxylem-groups towards each other. The process is precisely the same as in the roots of a Selaginella (Van Tieghem, I 87 I, p. 99, Pl. 5, Figs. 25 and 26), or in the rootlets of a Stigmaria. We have not examined the minute structure of the phloem of the root, which appears to resemble that of the leaf.

There are certain statements in the literature as to the roots of Isoetes which are not confirmed by our observations. Prof. Van Tieghem (189I, p. 1429) states that 'while the root is descending in the cortex, the structure of its central cylinder is binary, and at first normal ; the diametral band of xylem is parallel to the central cylinder of the stem. But gradually one sees the phloem-bundle situated on the side towards the axis of the stem, become more and more reduced, and finally disappear, while the diametral band becomes applied to, and concentrated towards the pericycle ${ }^{1}$ ' We can find nothing answering to this in Isoetes Hystrix.

However near the stele of the stem the root-trace is examined, its phloem is always limited to the side remote from the wood of the stem. Further, in this region, just as in the more distal parts of the root, the development of the xylem proves that its structure is monarch throughout. Fig. 33 shows a young root-bundle cut close to its junction with the stelar wood of the stem. There is manifestly one protoxylemgroup only, and the phloem, though as yet but little differentiated, is clearly limited to the side remote from the proto-

\footnotetext{
1 This account differs from that on p. 690 of the same work, where the normal structure in Isoetes, like that in Selaginella, is explained by abortion of one xylembundle, and fusion of the two groups of phloem.
} 


\section{Scott and Hill.-Structure of Isoetes Hystrix.}

xylem. At this point the primitive tracheides of the rootbundle are extremely short, showing the characters of those of the stele.

Prof. Bertrand (I88I, p. 5I) figures a root of Isoetes Hystrix in transverse section, and describes the roots of Isoetes as having a bicentric bundle, 'curved so strongly that some authors have considered these bundles as having only a single centre of development.' His figure clearly shows two protoxylem-groups side by side. We have seen no such structure in the roots of Isoetes, except at the point of bifurcation ; in every case the protoxylem is first differentiated as a single tracheide. At later stages, where several tracheides have become lignified, it might be possible to mistake some of the later-formed elements for a second group of protoxylem. Probably, however, Prof. Bertrand's interpretation is to be explained in a different way. His figure exactly represents the structure of an Isoetes root, at the point of bifurcation, the two protoxylem-groups belonging to the two forks of the dichotomizing bundle. Our Fig. 34 may be compared with Prof. Bertrand's, but ours was drawn from a section where the dichotomy was not quite as far advanced as it appears in his.

The whole of the evidence, so far at least as I. Hystrix is concerned, appears to us to leave no doubt that the structure of the root-stele is in all parts a strictly monarch one, and that there is at present no indication that this monarch organization has arisen by reduction from any more complex structure.

\section{SUMMARY。}

\section{The Stem.}

I. There is some evidence that the apex may grow by means of a single apical cell, as Hofmeister supposed.

2. The stele is not composed of the united leaf-traces, but is best interpreted as a cauline structure, comparable to that of the simpler Lycopods.

3. The differentiation of the primary wood is nearly simul- 
taneous over its whole area, but in some cases a centripetal development can be traced.

4. The cell-division of the primary meristem passes over without any interruption into that of the cambium.

5. In some cases the cambium is at first normal, lying on the inner side of the first-formed elements of the phloem, and producing secondary tracheides in contact with the primary wood. In this case a second cambium soon arises further to the exterior. In other specimens the more internal cambium arises after the other.

6. As a rule, the same cambium is active throughout, producing secondary ground-tissue, wood, and phloem, on its inner side, and cortical parenchyma only, towards the exterior.

7. Secondary wood is always formed, though very variable in amount. Its elements are typical tracheides, without cellcontents.

8. Well-differentiated phloem, consisting of enucleate elements, with clathrate pitting on their walls, is always present in the intracambial zone, forming definite, concentric bands, alternating with the secondary parenchyma. The phloem of the stem is continuous with that of the leaf-traces.

9. The stele, cylindrical above, becomes triquetrous below, owing to the abutment upon it of the root-bases, successively developed along lines corresponding to the furrows.

10. The development of the roots in each series is acropetal, while that of the several series belonging to each furrow is centripetal, with reference to the centre-line of the furrow.

II. The downward growth of the base of the stem is entirely due to the activity of the cambium, and to the addition of new root-bases.

\section{The Leaf.}

The general structure of the leaf is too well known to need recapitulation.

I. The vascular bundle, which is collateral throughout, has exarch structure in the lamina, the protoxylem lying next the 
phloem. The central canal of the bundle, which, with the lateral canals, when present, is surrounded by a true endodermis, represents the primitive row of tracheides. Their transverse walls are persistent, forming perforated diaphragms across the canal.

2. In the base of the leaf, and in the leaf-trace, there are no xylem-canals, and the structure of the bundles is in some cases mesarch, a few tracheides being formed between the protoxylem and the phloem.

3. The phloem contains true sieve-tubes with transverse sieve-plates, and lateral sieve-areas, on both of which callus is formed.

4. The growth of the leaf, except at its first origin, is intercalary.

5. The ligule, which develops extremely early, secretes mucilage when young. The glossopodium is surrounded by a sheath of tracheides, which are most abundantly developed in the base of the labium.

6. The labium and velum are derived from tissue above the sporangium, and not from sterilized sporogenous tissue. The velum shares in the intercalary growth of the leaf-base, and forms a complete pocket round the sporangium, only open by a narrow crevice at the base.

7. The persistent spinose scales are formed by sclerosis of certain portions of the tissue of the leaf-bases, whether fertile or sterile, as described by Alex. Braun.

\section{The Root.}

I. The stele of the root has, in all parts, a monarch structure, the differentiation of the xylem beginning with the development of a single tracheide, which lies directly opposite the protophloem. Neither at the base of the root nor elsewhere is there any indication of diarch structure.

2. The apex of the root shows distinct histogenetic layers, as described by Bruchmann, Farmer, and Campbell. The initial groups give rise to the plerome, and to the inner and outer cortex. 
The general structure and dichotomy of the root require no recapitulation.

\section{CONCLUSION.}

The investigation of Isoetes Hystrix shows that this terrestrial species differs less from the aquatic forms than might have been expected. The xylem throughout the plant is somewhat better developed, but the difference is not striking; the secondary wood, though a constant feature, is very variable in amount, and seldom plentiful. The leaves, with their numerous intercellular spaces, have an aquatic character, shown especially by the formation of the canals, with endodermal boundaries, in the xylem. This curious feature strongly suggests an aquatic adaptation, and it is singular to find it in a terrestrial plant. The whole structure indicates clearly that Isoetes Hystrix is in no way a primitive form, but rather represents an aquatic or amphibious type, which has become secondarily adapted to life on land.

While we thus find aquatic characters in a terrestrial species, it is interesting to recall the fact that terrestrial characters also appear in some of the aquatic species. Thus, A. Braun ( 1863 , p. 587$)$ points out that a large part of the genus, including several submerged forms, possesses stomata on the leaves.

We are thus naturally led to regard the genus Isoetes as a group that has long hovered on the limit of terrestrial and aquatic life, some of the forms becoming wholly submerged, while a few have definitely betaken themselves to dry land, a large proportion leading a more or less amphibious existence ${ }^{1}$.

For this reason, among others, we cannot accept $\mathrm{Mr}$. Wilson Smith's conclusion (1900, p. 323) that the genus Isoetes represents ' a more primitive form of sporophyte than any other vascular plant.' The group has clearly undergone

\footnotetext{
${ }^{1}$ In Baker's Fern-Allies, out of the forty-nine species described, nine are classed as aquatic, nine as subaquatic, twenty-nine as amphibious, and only two as terrestrial.
} 
reduction (in relation to aquatic habit) from some more complex type, and probably from some very highly organized form of Lycopod, as indicated by the secondary growth, the marked heterospory, and the somewhat complex organization of the leaves and of the root-bearing portions of the axis.

Our investigations have convinced us very strongly of the close Lycopodinean affinities of the genus, and of the absence of any special relationship to the Ferns. It will be necessary to consider briefly the points bearing upon this question. The Filicinean affinities of Isoetes have been maintained principally by Vines (1888), Farmer (1890), and Campbell (I891 and I895).

So far as the asexual plant is concerned, there can be no question that the sum of characters points clearly to Lycopodinean affinities, while, with the single, very doubtful exception of the velum, there is no single point in which the Ferns are approached. The habit of the plant, with its crowded, simple and narrow leaves, is more suggestive of Lycopods than of any other group. The fact that the stem is stunted appears to us to have no bearing on the question of affinities. Elongated and shortened forms of stem occur both in Lycopodiales and Filicales, and throughout the Vegetable Kingdom we find the greatest variety in this respect among closely related plants, and often within the limits of a single genus. Neither is the stunted form of stem by any means specially characteristic of the Ferns. The usually unbranched habit (which is not without exception) is no doubt correlated with the shortened form of stem ${ }^{1}$.

The anatomy of the stem, with its solid stele, from which densely crowded, small and simple leaf-traces pass off, is just what we should expect to find in a stunted Lycopod, and bears no real resemblance to anything in Ferns, though a general similarity between the simplest forms of any two groups is easy enough to find. Secondary tissue-formation is a character

${ }^{1}$ It should be remembered, however, that there is some evidence that many of the Palaeozoic Sigillariae branched little or not at all. 
of very little taxonomic value, and we know, chiefly through Williamson's researches, that it was of common occurrence in all groups of Vascular Cryptogams during the Palaeozoic period. The anomalous character of the secondary growth in Isoetes, however, agrees somewhat more nearly with that in certain fossil Lycopods, than with the process as known in any of the Filicales.

The discovery of Bruchmann that the base of the stem in Selaginella spimulosa (Bruchmann, I897, p. 39) shows an indefinite growth in thickness, is of great interest, as affording a new link between that genus and Isoetes. In this species of Selaginella the base of the stem is persistent, and is the only seat of root-formation. The development of secondary wood and parenchyma at the base of the stem is closely connected with the formation of successive new roots in the same region. The conditions, in fact, are closely comparable to those which prevail at the base of the stem in Isoetes. The minute histology of Isoetes is peculiar, for the tissueelements have been modified in relation to the habit. They show no approach to the structure of the corresponding tissues in Ferns.

In their whole structure, and especially in their monarch stele, the roots of Isoetes agree exactly with those of Selaginella and with the 'rootlets' of the Palaeozoic Stigmaria (subterranean organs of Lepidodendron and Sigillaria). So far as the dichotomous branching of the roots is concerned, the agreement extends to all known Lycopodiales. The apical structure of the Isoetes root agrees most nearly with that in the genus Lycopodium (Bruchmann, 1874). Taking the sum of the root-characters, they are throughout so typically Lycopodinean, that even regarded by themselves they would go a long way to establish affinity. Against this we have to set the fact that in a few species of Ophioglossum the roots are monarch, probably by reduction, and are said to be dichotomous in their mode of branching. In other species of the genus Ophioglossum, and in the majority of the family Ophioglosseae as a whole, the roots are diarch or polyarch in 
structure, and their branching monopodial ${ }^{1}$. If the peculiar characters of the root in certain species of Ophioglossum have any taxonomic significance (a doubtful point, which we cannot discuss here), they may indicate a certain approach to the Lycopods generally, but are no evidence of any special relation to Isoetes. The mode of origin of the roots of Isoetes has been compared to that in Marattiaceae, but there is no real agreement, for the Isoetes roots do not arise near the apex, or from the apical meristem, but are always limited to the lower part of the stem, and spring from a secondary tissue ${ }^{2}$. On the other hand, as already pointed out, they agree in these respects with the roots of such species of Selaginella as $S$. spinulosa.

Passing on to the leaves, and first considering their anatomy, we find that the single bundle, traversing the narrow leaf without branching, is in itself a Lycopodinean character, though a similar simple arrangement no doubt occurs in a few extremely reduced Filicales. The collateral structure of the bundle is unlike that in living Lycopods, so far as at present investigated, but agrees with the structure of the foliar bundles in the fossil Lepidodendreae. The agreement with the latter is far closer than with the large and branched collateral bundles in the leaf of Ophioglossum. In other respects the anatomy of the leaf in Isoetes affords no taxonomic indications. The development of the leaf almost entirely by intercalary growth, is, as Wilson Smith has pointed out (I900, p. 333), a marked Lycopodinean character, and forms a striking contrast to the apical foliar development of Ferns.

The general morphology of the leaf, i.e. of the sporophyll, is however of greater importance than any other character. The single large sporangium, seated on the upper side of the sporophyll, near its base, in position, development, and structure is typically Lycopodinean, and has no analogy with

\footnotetext{
${ }^{1}$ See Boodle, I899, on roots of Ophioglossum, and especially on monopodial branching in those of $O$. pendulum.

${ }^{2}$ The adventitious roots which grow down through the cortex in certain species of Lycopodium (e. g. L. squarrosum) appear to afford a better analogy with those of Marattiaceae.
} 
anything in Ferns. Isoetes is in fact, in this respect, the nearest living representative of the Palaeozoic Lepidodendreae (Bower, 1894); the form and large size of the sporangium, its attachment along the whole of its base to the median line of the ventral foliar surface, the presence of trabeculae, the heterospory, and the relation to the ligule, are all points in which there is a remarkably close agreement between Isoetes and Lepidostrobus (Maslen, 1899). This complete correspondence, at once so obvious and so exact, cannot be invalidated by a supposed analogy (remote, at the best) with the ventral spike of Ophioglossum vulgatum.

As regards the ligule, its homology with that of Selaginella or of the Lepidodendreae would seem manifest. Farmer (I 890) has endeavoured to dispute this, on the grounds that in Isoetes the ligule develops from a single cell, in Selaginella from a group of cells, and that it arises earlier, and is more elaborately developed in the former genus than in the latter. Harvey Gibson (1896) has shown that in the two latter points there is no marked difference between the two genera. The distinction as regards the number of initial cells holds good, but obviously affords no argument against homology in view of the close agreement in all other respects.

The velum of Isoetes has been compared with the indusium of a Fern, and regarded as forming the envelope of a 'monangic sorus,' as in the case of Lygodium or that of the megasporangium of Azolla. No Fern, however, is known in which the sporophyll produces a single 'monangic sorus,' and that in the ventral position. Until recently the velum of Isoetes was in so far a difficulty, that it appeared to be an isolated case among the Lycopodiales. Quite lately, however, one of us has found that in a Palaeozoic Lycopodinean cone, otherwise identical with a Lepidostrobus, each sporangium, whether containing microspores or megaspores, became enclosed in an integument, growing out from the sporophyll ${ }^{1}$. The integument in the fossil cone differs

1 See Scott, Studies in Fossil Botany, 1900, p. 180. A short account of this fructification (Lepidocarpon) has been communicated to the Royal Society, and a full description is in preparation. 
considerably in detail from the velum of Isoetes, but is sufficient to prove that the formation of a sporangial envelope is nothing foreign to the Lycopodiales. Mr. Kidston found some indications of a velum, like that of Isoetes, in the cone of Sigillaria, but the specimens not having their minute structure preserved, the conclusion to be drawn is somewhat uncertain.

One point, respecting the sporophyte, remains. In Isoetes most leaves are fertile, and there is no special strobilus. This fact scarcely affects the question of affinity, for we have almost the same conditions in some species of Lycopodium, i. e. $L$. Selago, where also no strobilus is differentiated, and there is a gradual transition from sporophylls to vegetative leaves. In the case of Isoetes, we much doubt whether this is a primitive character, for the plant altogether suggests, more than any other genus now living, the reduced successor of some of the gigantic Palaeozoic forms of Lycopodiales, all of which, so far as we know, were strobiloid.

The proposed transference of Isoetes from Lycopodiales to Filicales thus finds no support from the characters of the mature sporophyte. The prothallus and embryo lie beyond the scope of our present work, but we must shortly refer to their bearing on the main question.

As regards the prothallus, recent investigations have broken down the distinction formerly believed to exist between Selaginella and Isoetes, for the supposed differentiation of prothallus and endosperm in the former genus has proved to be illusory, and in reality development proceeds in a similar way in both genera.

The archegonia of Isoetes have been compared to those of the Eusporangiate Ferns, and no doubt with good reason, but the comparison is of no weight as against Lycopodinean affinities, for in the genus Lycopodium itself, as Campbell has well pointed out, 'the sexual organs closely resemble those of the eusporangiate Ferns and Equisetum' (Campbell, I 895, p. 466). Neither does there appear to be any definite distinction between the archegonia of Isoetes and those of Selaginella. 
A point on which stress is laid by Campbell is the presence of large, multiciliate spermatozoids in Isoetes, differing much from the small, biciliate spermatozoids of Lycopodium and Selaginella, and resembling those of Ferns and Equisetaceae. This seems to us the one character in which Isoetes really agrees with the two latter classes, rather than with the Lycopodiales as at present known. We have no desire to minimize the importance of this fact, but it cannot, as it seems to us, count for much against the aggregate of Lycopodinean characters.

The embryology has also been much relied on by the advocates of Filicinean affinities, but the resemblance of the embryo of Isoetes to that of Ferns appears a remote one. In Ferns the cotyledon and stem arise from the epibasal half of the embryo, the root and foot from the hypobasal half, and all the organs are, as a rule, marked out extremely early. In Isoetes the root arises, with the cotyledon, from the epibasal half, while the lower portion produces the foot only. The stem is not one of the primary structures of the embryo at all, but appears quite late, between the cotyledon and the root. Botrychium ${ }^{1}$ appears to resemble Isoetes in the origin of the root from the same half of the embryo as the stem; it differs, however, from our genus, in the fact that the stem precedes the cotyledon in its development. It may be doubted whether the Isoetes-embryo, apart from the absence of a suspensor, does not agree quite as nearly with that of a Lycopodium as with the embryo of a Fern. The suspensor, however, is known to be a very inconstant feature in other groups of plants; in some Leguminosae, for example, it is altogether absent, while in others it constitutes almost the whole of the embryo at an early stage.

Taking the whole of the known characters of Isoetes, we see no reason to depart from the view, which for half a century has generally prevailed among botanists, that Isoetes is a true Lycopod. The recent ingenious attempts to connect the genus with the Filicales have not rested on any new discoveries, but have probably been unconsciously influenced by

1 Jeffrey, 1897 .

$\mathrm{H} \mathrm{h}$ 
$45^{\circ}$ Scott and Hill.-Structure of Isoetes Hystrix.

the desire to find a heterosporous representative of the Eusporangiate Ferns.

Mr. Wilson Smith, in his recent paper, has stated with much force the arguments for the Lycopodinean affinities of Isoetes. In addition to points which we have mentioned above, he calls attention to the extremely early development of the sporangium in Isoetes, to its multicellular archesporium, and its indehiscent character.

As to the position of Isoetes within the Class Lycopodiales, the genus appears to have some real affinity with Selaginella, though not close enough to render it desirable to keep them in the same Family. The relationship of Isoetes to the Lepidodendreae is probably a nearer one ${ }^{1}$. It may possibly turn out that the curious Triassic genus Pleuromeia, of which we have recently had a full description from Count SolmsLaubach (1899), may have been in some respects intermediate between the arborescent Palaeozoic Lycopods and the reduced genus Isoetes. We have not thought it necessary to discuss certain resemblances which have been suggested between Isoetes and the Monocotyledons. Much further evidence will be required before these apparent points of similarity can be accepted as any indication of affinity.

1 On this point compare Bertrand Cornaille et Hovelacque, Remarques sur la Structure des Isoetes. Saint-Étienne, I 897. 


\section{Literatúre Cited.}

BAKER, J. G., 1887 : Handbook of the Fern-Allies. London.

Bertrand, C. E., 1881: Définitions des Membres des Plantes Vasculaires. Archives Bot. du Nord de la France, vol. i.

Boodle, L. A., 1899: On some points in the Anatomy of the Ophioglosseae. Annals of Botany, vol. xiii.

Bower, F. O., 1894: Studies in the Morphology of Spore-producing Members; I. Equisetineae and Lycopodineae. Phil. Trans. Roy. Soc., vol. clxxxv. B.

Braun, A., 1863 : Ueber die Isoetes-Arten der Insel Sardinien. Monatsberichte d. K. Preuss. Akad. der Wiss. zu Berlin ; aus dem Jahre 1863.

Bruchmann, H., 1874 : Ueber Anlage u. Wachsthum der Wurzeln von Lycopodium u. Isoetes. Jenaische Zeitschrift f. Naturwiss., vol viii. 1897 : Untersuchungen uiber Selaginella spinulosa. Gotha.

CAMPBELI, D. H., 1891 : Contributions to the Life-History of Isoetes. Annals of Botany, vol. v. London.

De Bary, A., 1884: Comparative Anatomy of the Phanerogams and Ferns. English Translation, Oxford.

Farmer, J. B., 1890: On Isoetes lacustris. Annals of Botany, vol. v.

Gibson, R. J. Harvey, 1894: Contributions towards a Knowledge of the Anatomy of the genus Selaginella; I. The Stem. Annals of Botany, vol. viii.

1896: Do. II. The Ligule. Ann. of Bot., vol. $x$. 1897 : Do. III. The Leaf. Ann. of Bot., vol. xi.

Hegelmaier, F., 1874 : Zur Kenntniss einiger Lycopodinen. Botanische Zeitung, vol. xxxii.

Hofmeister, W., 1852 : Beiträge zur Kenntniss der Gefäss-Kryptogamen; I. Die Entwickelungsgeschichte der Isoetes lacustris. Abhandl. der K. Sächs. Ges. d. Wissensch., vol. iv. Translated in Germination Development and Fructification of the Higher Cryptogamia. Ray Society, 1862.

JANCZEWSKI, E. DE, 1882: Études comparées sur les Tubes cribreux. Ann. des Sci. Nat. (Bot), Ser. 6, vol. xiv.

JefFrey, E. C., 1897: Gametophyte of Botrychium Virginianium. Trans. Canadian Institute, vol. v, Part 2.

Kienitz-GerlofF, F., 1881: Ueber Wachsthum u. Zelltheilung, und die Entwickelung des Embryos von Isoetes lacustris. Botanische Zeitung, vol. xxxix.

KRUCH, O., 1890: Istologia ed istogenia del fascio conduttore delle foglie di Isoetes. Malpighia, vol. iv.

Marquand, E. D., 1889: On the genus Isoetes. Trans. Guernsey Society of Natural Science, 1889 .

MasLen, A. J., 1898 : The Ligule in Lepidostrobus. Annals of Botany, vol. xii. 1899 : The Structure of Lepidostrobus. Trans. Linnean Soc. of London, Ser. 2, vol. v.

H h 2 


\title{
452. Scott and Hill.-Structure of 1soetes Hystrix.
}

Moнl, H. von, 1845: Ueber den Bau des Stammes von Isoetes lacustris. Vermischte Schriften, p. I22. First published in Linnaea for 1840.

Motelay, L., et Vendryés, 1882 : Monographie des Isoeteae. Actes de la Soc. Linn. de Bordeaux, vol. xxxvi.

NäGeLI, C., n. LeITGEB, H., 1868: Entstehung u. Wachsthum der Wurzeln. Beiträge zur wiss. Botanik, Heft IV.

Russow, E., 1872 : Vergleichende Untersuchungen ... Leitbündel-Kryptogamen. St. Petersburg.

ScotT, D. H., 1900 : Studies in Fossil Botany. London.

Smith, Wilson R., 1900: Structure and Development of the Sporophylls and Sporangia of Isoetes. Botanical Gazette, vol. xxix.

Solms-Laubach, Graf H. zu, 1899 : Ueber das Genus Pleuromeia. Botanische Zeitung, vol. lvii.

Strasburger, E., 1891 : Histologische Beiträge, vol. iii.

Van Tieghem, Ph., 1871: Recherches sur la Symétrie de Structure des Plantes Vasculaires. Ann. des Sci. Nat. (Bot.), Ser. 5, vol. xiii.

Traité de Botanique. Second edition, I89r. et Douliot, H., 1888: Recherches comp. sur l'origine des membres endogènes. Ann. des Sci. Nat. (Bot.), Ser. 7, vol. viii.

Vines, S. H., 1888: The Systematic Position of Isoetes. Ann. of Bot., vol, ii, Pp. II 7 and 223 .

\section{EXPLANATION OF FIGURES IN PLATES XXIII AND XXIV.}

\author{
Illustrating Messrs. Scott and Hill's paper on Isoëtes Hystrix.
}

\section{PLATE XXIII.}

Fig. I. Apical meristem of stem, in superficial transverse section. a, two large central cells, of which one may be the apical cell and the other its segment. $\times 576$.

Fig. 2. Part of a similar section from another apex. $a$, apparent apical cell. $\times 6$ ro.

Fig. 3. Apical meristem of stem in median longitudinal section. a, apparent apical cell. $\times 55^{\circ}$.

Fig. 4. Adjacent section to the last. $s$, segment-cells. $\times 55^{\circ}$.

Fig. 5. Transverse section of the upper part of the stele, from a young stem. $x$, primary wood; l.t, leaf-trace; $c b$, cambium. The enucleate cells between cambium and wood belong largely to the phloem. $\times 207$.

Fig. 6. Transverse section of the wood of the stele, cut near the apex. $x$, xylemelements; the differentiation has not yet reached the centre. From a larger stem than Fig. 5. $\times$ about 200 .

Fig. 7. Peripheral tissues of the stele, in transverse section. $x$, part of primary 


\section{Scott and Hill.-Structure of Isoetes Hystrix.}

xylem; $x^{2}$, secondary xylem, in course of differentiation; $p h$, phloem, showing clathrate cell-walls; $c b$, cambium. $\times 4^{2}$.

Fig. 8. Similar section, from another stem, at the commencement of secondary growth. $x$, primary xylem; $c b$, cambium; ph, phloem, lying outside cambium. $\times 300$.

Fig. 9. Secondary tracheide, $x^{2}$, in longitudinal section, isolated among cells of the secondary parenchyma. The primary wood is on the side $X . \times 360$.

Fig. Io. Secondary tissues in longitudinal section, from an old part of stem. $X$, direction of primary wood; $p h^{2}$, obliterated secondary phloem ; $x^{2}$, secondary xylem; $c b$, cambium; $c$, secondary cortex. $\times 180$.

Fig. II. Transverse section, showing well-developed secondary xylem, $x^{2}$. $c b$, cambium ; $X$, direction of primary wood. $\times 325$.

Fig. I2. Secondary xylem $\left(x^{2}\right)$ and phloem $\left(p h^{2}\right)$ in transverse section. The latticed structure of the phloem cell-walls is well shown. L.T, phloem of leaf-trace, continuous with that of stem; $X$, direction of primary wood. $\times 340$.

Fig. 13. Diagrammatic transverse section of the upper, cylindrical part of the stele. $x$, primary wood; $p h^{2}$, region in which secondary phloem; $x^{2}$, that in which secondary xylem is developed; $c b$, cambium; $c^{2}$, secondary cortex ; l.t, leaf-traces. $\times 68$.

Fig. 14. Diagrammatic transverse section of the lower, triquetrous part of the stele. $r t$, adventitious roots; other letters as before, but no secondary xylem present. $\times 22$.

Fig. 15. Transverse section, showing one arm of the triquetrous part of stele. $x$, primary xylem, much disorganized; $c b$, cambium; $r t$, root-traces, of which several are shown; $p h$, phloem, and $x$, xylem, of a root-trace. $\quad \times 213$.

\section{PLATE XXIV.}

Fig. 16. Phloem $\left(p h^{2}\right)$ from stem, showing pitted cell-walls, and beginning of formation of callus (?). $\times 576$.

Fig. 17. Obliterated cells of phloem $\left(p h^{2}\right) . \times 576$.

Fig. 18. Diagrammatic transverse section of lamina of leaf, showing intercellular cavities, stomata, fibrous strands, and vascular bundle. $x$, xylem; ph, phloem; Gc, stoma. $\times 17$.

Fig. 19. Transverse section showing structure of foliar bundle in the lamina. $x$, xylem, five tracheides shown; $p x$, canal, marking position of primitive tracheide ; a fragment of its lignified wall is shown; to the right and left are the other two xylem-canals; ph, phloem. $\times 310$.

Fig. 20. Transverse section (cut just above sporangium) of a very young foliar bundle. $p x$, the primitive tracheide, from which the central canal will be formed; this is at present the only lignified element; $p p h$, protophloem. $\quad x$ about $43 \circ$.

Fig. 2I. Transverse section from a partly developed leaf, showing a persistent transverse wall of the protoxylem, forming a perforated diaphragm across the canal. $\times 680$.

Fig. 22. Foliar bundle of lamina, in radial section. $x$, a tracheide of the xylem; $p x$, protoxylem, now forming a canal, crossed by a persistent transverse wall ; $p h$, phloem. $\times 296$.

Fig. 23. Corner of lamina in transverse section, showing a fibrous strand. $\times 280$. 


\section{Scott and Hill.-Structure of Isoetes Hystrix.}

Fig. 24. Callose sieve-plate, shown in longitudinal section of a sieve-tube in the foliar bundle. $\times 1650$.

Fig. 25. Sieve-tubes from foliar bundle, showing sieve-areas on the lateral walls. $\times 720$.

Fig. 26. Diagrammatic radial section of the base of a sporophyll. $l g$, ligule; $l a b$, labium; $i$, velum; $t r$, trabeculae in sporangium; $x$, xylem; $p h$, phloem of the foliar bundle; $t$, subligular tracheal sheath.

Fig. 27. Radial section of rather young leaf, showing base of ligule, $\lg ; t$, tracheal sheath, seen on either side of the ligular base. $\times 160$.

Fig. 28. Spinose leaf-base, seen obliquely from above, and from the dorsal side. $\times 8$.

Fig. 29. Whole plant, seen obliquely from beneath, after removing the roots and spinose leaf-bases; the three furrows and the living sporophylls are shown. $\times \frac{3}{2}$.

Fig. 3o. Root, in somewhat diagrammatic transverse section. $x$, xylem; $p x$, protoxylem; ph, phloem; $c$, cortex. $\times 68$.

Fig. 31. Central part of the root, in transverse section, showing stele and intercellular cavity. end, endodermis; $x$, xylem; ph, phloem. $\times 3^{20}$.

Fig. 32. Young stele of root, in transverse section. $p x$, protoxylem, the only element as yet lignified; $p h$, phloem, adjacent to endodermis. $\times 580$.

Fig. 33. Young root-trace, close to stele of stem, in transverse section. $p x$, protoxylem, two tracheides lignified at this stage; $p h$, phloem in course of development. $\times$ about 400 .

Fig. 34. Root-stele, in transverse section, at the base of a dichotomy. $x$, xylem, widely expanded laterally; $p h$, phloem. $\times$ about 400 . 


\section{$2 \mathrm{BHL}$ Biodiversity Heritage Library}

Scott, Dukinfield Henry and Hill, T. G. 1900. "The structure of Isoetes hystrix." Annals of botany 14, 413-454.

https://doi.org/10.1093/oxfordjournals.aob.a088787.

View This Item Online: https://www.biodiversitylibrary.org/item/238259

DOI: https://doi.org/10.1093/oxfordjournals.aob.a088787

Permalink: https://www.biodiversitylibrary.org/partpdf/318594

\section{Holding Institution}

Smithsonian Libraries

\section{Sponsored by}

Biodiversity Heritage Library

\section{Copyright \& Reuse}

Copyright Status: Not in copyright. The BHL knows of no copyright restrictions on this item.

This document was created from content at the Biodiversity Heritage Library, the world's largest open access digital library for biodiversity literature and archives. Visit BHL at https://www.biodiversitylibrary.org. 